\title{
腔悪性腫瘍手術における術前貯血式および希釈式自己血輸血の適応
}

\author{
大関 “悟·高木潤吉 $\cdot$ 大部一成・渡辺伸哉 \\ 後藤圭也·大石正道・久保敬司*
}

\section{Indications for predeposit autologous blood transfusion and hemodilution in patients undergoing operations for oral malignant tumors}

\author{
Satoru Ozeki $\cdot$ Junkichi Takaki $\cdot$ Kazunari Oobu $\cdot$ Shinya Watanabe \\ Keiya Gото • Masamichi OнishI · Keiji KuBo*
}

\begin{abstract}
Predeposit autologous blood transfusion combined with recombinant human erythropoietin ( $\mathrm{r}-\mathrm{HuEPO}$ ) has been used at our department since 1995 in patients undergoing operations for oral malignant tumors. This decision was based on studies of blood loss and homologous transfusions in past operations. In this report we discuss the indications, methods and issues of autologous blood transfusion in patients undergoing operations for oral malignant tumors.

Among 88 patients who underwent operations for oral malignant tumors between 1993 and 1995, 40 had blood loss of over $600 \mathrm{ml}$ and $24(60 \%)$ received homologous transfusions. We estimated the average blood loss according to the operation procedure by dividing the patients into seven groups depending on the extent of resection of the primary lesion and whether or not radical neck dissection and reconstruction were performed.

Predeposit autologous blood transfusion combined with recombinant human erythropoietin ( $\mathrm{r}$-HuEPO) was given to 13 patients who suffered blood loss of over $600 \mathrm{ml}$ during operations performed 1 year since June 1995. The volume of predeposit blood ranged from 400 to $1600 \mathrm{ml}$, averaging $1015 \mathrm{ml}$.

As for the effect of $\mathrm{rHuEPO}$, five patients showed an excellent response and three showed a moderate response; the response rate was $67 \%$ ( $8 / 13$ ). Blood loss up to $2200 \mathrm{ml}$ could be compensated by predeposit autologous blood transfusion of $1600 \mathrm{ml}$. Therefore, predeposit autologous blood transfusion combined with r-HuEPO was considered safe and effective when used in patients who undergo operations for oral malignant tumors and have a large volume of blood loss.

Based on our clinical experience, we established schedules for collection of 800,1200 , and $1600 \mathrm{ml}$ of predeposit autologous blood within 6 weeks with the use of MAP preservative solution.
\end{abstract}

Key words: autologous blood transfusion (自己血輸血), oral malignant tumor (口腔悪性腫瘍), erythropoietin (エリスロポエチン)

九州大学歯学部口腔外科学第 1 講座

(主任 : 大石正道教授)

*九州大学歯学部附属病院歯科麻酔科

(主任 : 池本清海教授)

First Department of Oral and Maxillofacial Surgery, Faculty of Dentistry, Kyushu University
(Chief: Prof. Masamichi Ohishi)

* Department of Dental Anesthesiology, University Dental Hospital Attached to the Faculty of Dentistry, Kyushu University (Chief: Prof. Yoshimi Ikemoto)

受付日：平成 9 年 8 月 18 日 
緒 言

近年, 同種血輸血に伴う合併症を回避する目的で, 多くの分野での手術において自己血輸血が普及してき た. 自己血輸血法は貯血式, 希釈式, 回収式があるが, このうち液状保存での貯血式は, 簡便で経済的かつ安 全で確実性があるため, 最も汎用性がある自己血輸血 法である ${ }^{1)}$ ，貯血式自己血輸血の適応として，待機 （予定）手術であること，手術術式が一定で術中出血量 が子測できること，全身状態が良好（術前に筫血のな い症例）であること，などがあげられる．口腔悪性腫 瘍の手術では拡大手術や種々の再建に伴う出血のため 輸血する症例が多いが, 一般に悪性腫崵患者において は, 待機手術でないことや術前の放射線療法や化学療 法による骨揈機能抑制, それに伴う筫血や全身状態の 低下などの問題点があり，術前の自己血貯血が困難で あるとされていた。

しかし，赤血球造血因子製剂である遺伝子組換えヒ トエリスロポエチン (recombinant human erythropoietin: 以下, rHuEPO) が貯血後の筫血改善に用い ることができるようになり2，全身状態や造血能の低 下した悪性腫揚患者に抏いても術前の自己血貯血が可 能となってきた. 私たちはこれまでの当科における口 腔悪性腫場手術での出血量と輸血の状況をふまえた上 で, rHuEPOを併用した術前貯血式自己血輸血を開始 した.そこで今回，口腔悪性腫場患者の手術における 自己血輸血の適応, 方法, 問題点について検討し報告 する。

\section{対象および方法}

当科において自己血輸血を開始する前の 2 年 2 か月 間（1993年 4 月から1995年 5 月まで）に手術が行われ た口腔悪性腫瘍症例88例を対象として, 術中出血量と 輸血の状況を調べ, 術式による出血量の予測が可能で
あるかを検討したまたた術前治療を行った 32 例につ いて, 術前治療前後のへモグロビン（以下， $\mathrm{Hb}$ ）值の 変動を調べ, 術前貯血の可否について検討した。

当院において $\mathrm{rHuEPO}$ が使用可能となった1995年 6 月から1996年 5 月までの 1 年間に手術を行った口腔 悪性腫瑒症例 40 例のうち, $600 \mathrm{ml}$ 以上の出血が予測さ れた13例において術前貯血式自己血輸血を施行した。 貯血量は予測出血量にしたがって400から $1600 \mathrm{ml}$ 行い, 貯血の時期は原則として術前治療終了から手術までの $2 \sim 3$ 週間を利用したが，各症例の $\mathrm{Hb}$ 值や貯血量に 応してて, 術前治療開始前や治療中にも貯血を行った。 $\mathrm{rHuEPO}$ (エポジン ${ }^{\circledR}$ の投与は 1 回 $400 \mathrm{ml}$ の貯血に 対して貯血当日に 1 回6000国際単位 (IU) を静脈内投 与し, 以後隔日に 2 回, 計 3 回18000IU を投与した。 ま た鉄剂としてクエン酸第一鉄ナトリウム（フェロミ $\left.ア^{\circledR}\right) を 200 \mathrm{mg} /$ 日の経口投与を併用した.この自己血 輸血症例を対象として眝血の量, 期間, 保存方法およ び䝪血と $\mathrm{rHuEPO}$ 投与による $\mathrm{Hb}$ 値の変動と $\mathrm{Hb}$ 增 加量を調べ, rHuEPO の有用性と至適貯血方法につい て検討した.

\section{結果}

\section{1. 手術術式と出血量}

口腔悪性腫場の手術術式を原発巣の部位や切除の程 度と頸部郭清および再建の有無によって7 群に分類し て, 出血量を検討した (表 1 ). 原発巣のみの切除では 上頻全切除 (C群) において平均 $987 \mathrm{ml}$ の出血がみら れ1例に同種血輸血が行われていた. 全頸部郭清術単 独 (D 群) では259 736 $\mathrm{ml}$, 平均 $466 \mathrm{ml}$ の出血がみら れたが，1例も輸血は行われていなかった。原発巣切 除と頸部郭清を含めた en-bloc 手術（E 群：13例）で は平均 $768 \mathrm{ml}$ の出血量で, 6 例に輸血が行われていた. さらに有茎筋皮弁や遊離（筋）皮弁による再建加加わっ た症例 ( $\mathrm{F}$ 群 : 10例) では, 全例 $500 \mathrm{ml}$ 以上の出血が

表 1 口腔悪性腫瘍の手術術式と出血量

(1993. $4 \sim 1995.5$ )

\begin{tabular}{|c|c|c|c|c|c|c|c|c|}
\hline 式 & 症例数 & 出血量 & 平均 & 同種血輸血 & 輸血率 & 輸血量 & 平均 & 非輸血例 \\
\hline A. 軟組織部分切除 & 35 & $10 \sim 370$ & 80 & 0 & 0 & - & - & 0 \\
\hline B. 下顎骨切除術 & 8 & $130 \sim 654$ & 282 & 0 & 0 & - & - & $1 / 1$ \\
\hline C. 上顎全切除術 & 3 & $750 \sim 1360$ & 987 & 1 & 33 & 400 & 400 & $1 / 2$ \\
\hline D. 全頸部郭清術 & 8 & $259 \sim 736$ & 466 & 0 & 0 & - & - & $2 / 3$ \\
\hline E. 部分切除+郭清 & 13 & $370 \sim 1052$ & 768 & 6 & 46 & $400 \sim 800$ & 633 & $1 / 6$ \\
\hline F. 部分切除＋郭清＋再建 & 10 & $550 \sim 1783$ & 1056 & 6 & 60 & 800 & 800 & $2 / 4$ \\
\hline G. 拡大切除 + 郭清 + 再建 & 11 & $698 \sim 2496$ & 1650 & 11 & 100 & $800 \sim 2400$ & 1490 & - \\
\hline 計 & 88 & & & 24 & $27 \%$ & & & $7 / 16^{*}$ \\
\hline
\end{tabular}

*術後 Hb10以下／出血量 $600 \mathrm{cc}$ 以上 

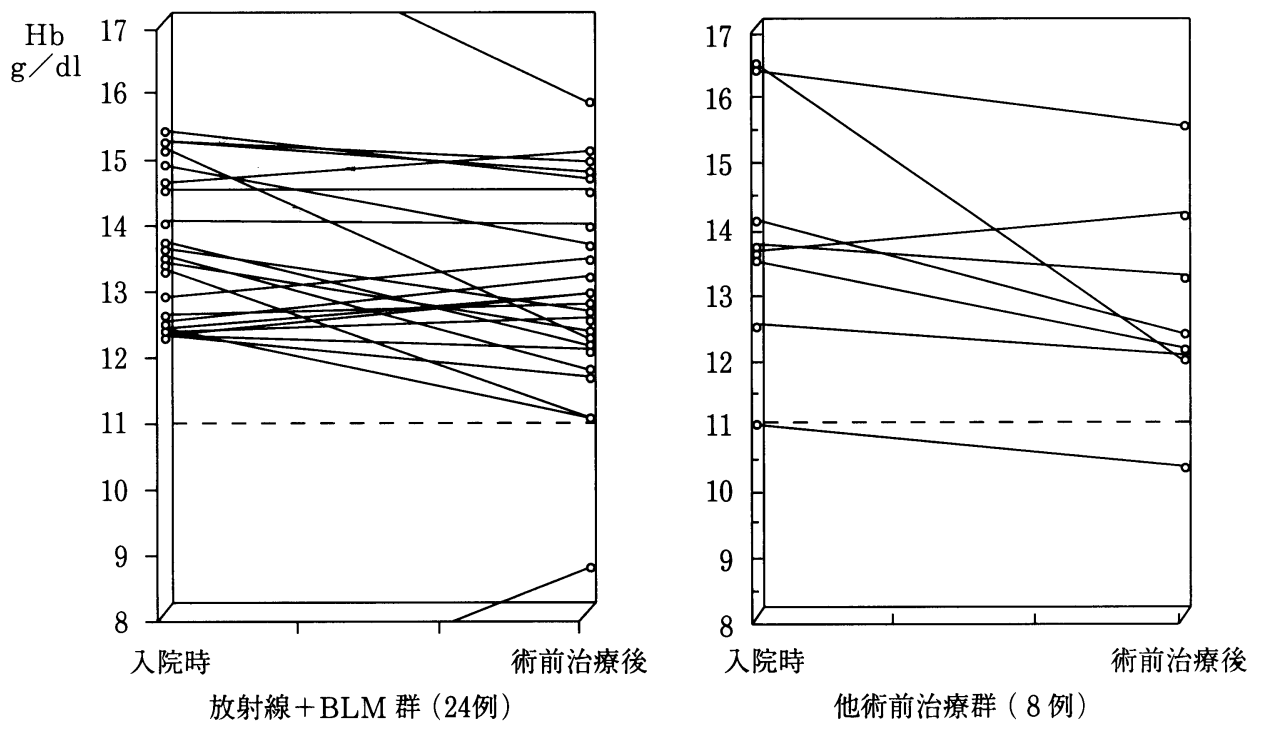

図 1 術前治療による $\mathrm{Hb}$ 值の変動

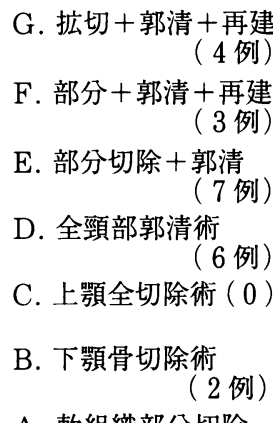

A. 軟組織部分切除

(18例)
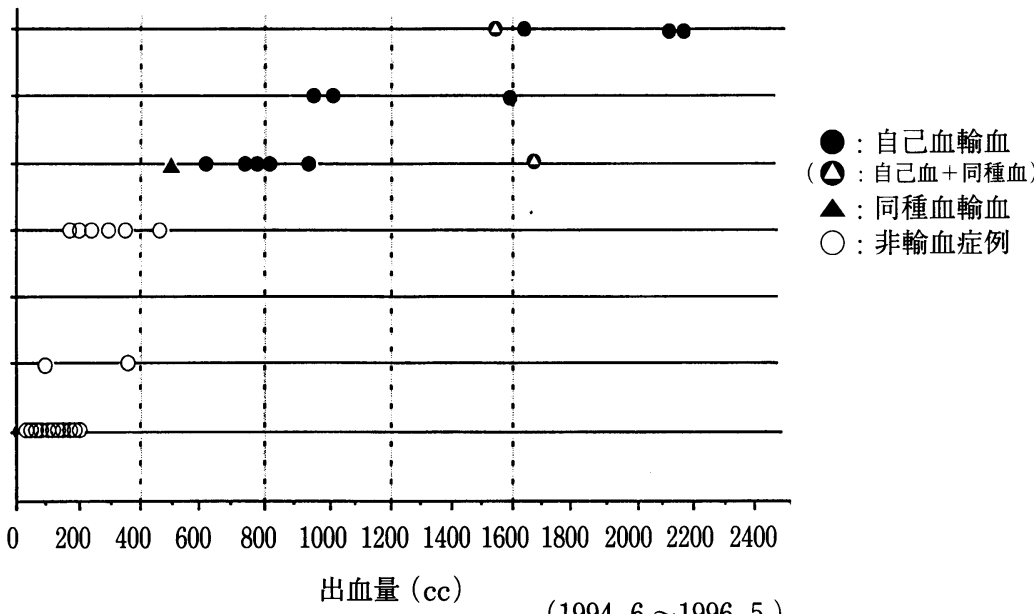

図 2 口腔悪性腫瘍手術における出血量と輸血

みられ, 平均 $1056 \mathrm{ml}$ で 6 例に輸血が行われていた. 原 発巣の切除が広範囲の軟組織や上下顎骨を含んだ拡大 手術 ( $\mathrm{G}$ 群 : 11例) においては698〜2496ml, 平均 1650 $\mathrm{ml}$ で, 全例に輸血が行われていた。

各群の輸血施行率は A, B, D 群は $0 \%, C$ 群 $33 \%$ ( $1 / 3)$, E 群 $46 \%(6 / 13), \mathrm{F}$ 群 $60 \%(6 / 10), \mathrm{G}$ 群100\% (11/11) であった. $600 \mathrm{ml}$ 以上の出血がみら れた40例のうち24例に同種血輸血が行われており， $600 \mathrm{ml}$ 以上の出血例における同種血輸血の回避率は 40 \% (16/40) であった. しかし，この輸血を行わなかっ た 16 症例のうち 7 例において術後の $\mathrm{Hb}$ 值が $10 \mathrm{~g} / \mathrm{dl}$ 以下の筫血がみられた。

\section{2. 口腔覀性腫瘍患者の術前 $\mathrm{Hb}$ 值（図 1 ）}

術前治療を行った 32 症例のうち入院時 $\mathrm{Hb}$ 值が $11 \mathrm{~g}$ $/ \mathrm{dl}$ 未満であったのは 2 例のみで残り 30 例は $12 \mathrm{~g} / \mathrm{dl}$ 以上であり, 20例は $13 \mathrm{~g} / \mathrm{dl}$ 以上と良好な $\mathrm{Hb}$ 值であっ た. 術前治療後の $\mathrm{Hb}$ 值の低下が最も大きかったのは, 化学療法の多剂併用 (VAC-ADR) を行った症例で, 強い骨髄抑制のため $4.5 \mathrm{~g} / \mathrm{dl}$ の低下を認めた.しかし， 当科での術前治療の主体であるブレオマイシン (BLM) $110 \mathrm{mg}$ と $22.5 \mathrm{~Gy}$ の放射線併用療法は骨䯣抑制がほと んどなく，この術前治療を行った 24 例の $\mathrm{Hb}$ 值の低下 は平均 $0.43 \mathrm{~g} / \mathrm{dl}$ と軽度であった。術前治療後30例に おいて貯血可能である $11 \mathrm{~g} / \mathrm{dl}$ 以上の $\mathrm{Hb}$ 值を保って 
表 2 自己血輸血症例

(1995. $6 \sim 1996.5)$

\begin{tabular}{|c|c|c|c|c|c|c|c|c|c|c|c|}
\hline 症例 & 年齢 & 性 & $\begin{array}{l}\text { 手術 } \\
\text { 術式 }\end{array}$ & 術 前 治 療 & 貯血量 & 貯血期間 & 保存方法 & 希釈式 & 出血量 & 自己血輸血 & 同種血輸血 \\
\hline 1 & 49 & 女 & $\mathrm{E}$ & - & 400 & 1 週間 & 液 & & 777 & 400 & \\
\hline 2 & 33 & 女 & $\mathrm{E}$ & - & 400 & 1 & 状 & 400 & 1696 & 800 & 400 \\
\hline 3 & 56 & 男 & $\mathrm{E}$ & $22.5 \mathrm{~Gy}+\mathrm{BLM}$ & 800 & 2 & 状 & & 617 & 800 & \\
\hline 4 & 73 & 男 & $\mathrm{E}$ & $30 \mathrm{~Gy}+\mathrm{UFT}$ & 800 & 2 & 状 & & 794 & 800 & \\
\hline 5 & 59 & 男 & $\mathrm{E}$ & $22.5 \mathrm{~Gy}+\mathrm{BLM}$ & 800 & 2 & 状 & & 952 & 800 & \\
\hline 6 & 70 & 男 & $\mathrm{E}$ & - & 800 & 2 & 状 & & 768 & 800 & \\
\hline 7 & 72 & 男 & G & - & 800 & 2 & 状 & & 1577 & 800 & 400 \\
\hline 8 & 52 & 男 & G & $22.5 \mathrm{~Gy}+\mathrm{BLM}$ & 1200 & 3 & 液 & 400 & 2156 & 1600 & \\
\hline 9 & 61 & 女 & $\mathrm{F}$ & $22.5 \mathrm{~Gy}+\mathrm{BLM}$ & 1200 & 6 & 状 & & 1015 & 1200 & \\
\hline 10 & 28 & 男 & G & $\mathrm{CDDP}+\mathrm{ADR}$ & 1200 & 9 & 凍結＋液状 & 400 & 1631 & 1600 & \\
\hline 11 & 64 & 男 & $\mathrm{F}$ & $22.5 \mathrm{~Gy}+\mathrm{BLM}$ & 1600 & 7 & 状* & & 1600 & 1600 & \\
\hline 12 & 70 & 男 & F & $22.5 \mathrm{~Gy}+\mathrm{BLM} \cdot \mathrm{CDBCA}$ & 1600 & 6 & 凍結＋液状 & & 936 & 1200 & （400廃棄） \\
\hline 13 & 51 & 男 & G & $22.5 \mathrm{~Gy}+\mathrm{BLM} \cdot \mathrm{CDBCA}$ & 1600 & 6 & 凍結＋液状 & 400 & 2142 & 2000 & \\
\hline
\end{tabular}

いた。

\section{3 . 自己血輸血症例}

1995年 6 月以降の 1 年間に $600 \mathrm{ml}$ 以上の出血が予測 された13例に術前貯血を行い自己血輸血を施行した. 13例のうち男性 10 例, 女性 3 例で, 年齢は 28 から 73 歳, 平均56.8歳であった. 手術術式は $\mathrm{E}$ 群 7 例, $\mathrm{F}$ 群 3 例, $\mathrm{G}$ 群 4 例で, $\mathrm{E}$ 群以上の術式で自己血輸血を行わなかっ たのは 1 例のみであった (図 2 ). また, 出血量が貯血 量を大幅に上回り同種血輸血を併用した症例が 2 例あ $\eta$, 結局 $600 \mathrm{ml}$ 以上の出血がみられた 13 例のうち 2 例 に同種血輸血が行われており，同種血輸血の回避率は 84.6\% (11/13) であった.

\section{1 ) 貯血方法}

自己血輸血を行った13症例の一覧を表 2 に示す．貯 血量は $400 \mathrm{ml} 2$ 例, $800 \mathrm{ml} 5$ 例, $1200 \mathrm{ml} 3$ 例, $1600 \mathrm{ml}$ 3 例でいずれも 1 回貯血量は $400 \mathrm{ml}$ であった. 貯血期 間は $400 \mathrm{ml}$ が 1 週間， $800 \mathrm{ml}$ が 2 週間であったが, $1200 \mathrm{ml}$ では 1 週間毎に 3 週間で貯血を行ったのは 1 例のみで， 6 週間， 9 週間各 1 例, $1600 \mathrm{ml}$ では 6 週間 2 例， 7 週間 1 例であった。保存方法は MAP 保存液に よる液状保存を原則としたが, 保存可能期間の 6 週間 を越える症例は術前治療前貯血の凍結保存 ( 3 例) や スイッチバック法 $\left.{ }^{3}\right)$ (1 例)を行った。また予測出血 量に対し貯血量が不十分と思われた 4 症例は術直前採 血による希釈式を併用した。症例 $2 ， 7$ は出血量が貯 血量を大きく上回ったため, $400 \mathrm{ml}$ の同種血輸血を併 用した. 一方, 症例 7 は $1600 \mathrm{ml}$ の貯血に対して出血量 が $936 \mathrm{ml}$ であったため, 戻し輸血を $1200 \mathrm{ml}$ 行い, 自己 血 $400 \mathrm{ml}$ が廃棄された。

\section{2 ) $800 \mathrm{ml}$ 貯血症例}

3 例においては 3 週間の放射線照射 $22.5 \mathrm{~Gy}$ と BLM $110 \mathrm{mg}$ 同時併用後, 手術までの 2 週間の休止期間に 1 回 $400 \mathrm{ml}$ を 1 週間間隔で $800 \mathrm{ml}$ 貯血した. 2 例は術前 治療を行わなかったため, 入院から手術までの術前検 查期間を利用して行った（図 3 ).

$\mathrm{Hb}$ 值の変動は 1 回 $400 \mathrm{ml}$ 貯血により約 $1 \mathrm{~g} / \mathrm{dl}$ の 低下がみられ, rHuEPO 投与によりある程度の $\mathrm{Hb}$ の 回復が見られるものの, 貯血前の值まで回復する症例 はみられなかった. 手術前日までの $\mathrm{Hb}$ 值の低下は 5 症例ともほとんど同じで, 平均 $1.3 \mathrm{~g} / \mathrm{dl}$ であった。 $1600 \mathrm{ml}$ の出血のため同種血輸血 $400 \mathrm{ml}$ を併用した症 例 7 を除いた他の 4 例は出血量が $800 \mathrm{ml}$ 前後であり, 自己血 $800 \mathrm{ml}$ の輸血により術後 7 日目までに貯血前の $\mathrm{Hb}$ 值まで回復した（図 3 ).

3 ) $1200 \mathrm{ml}$ 貯血症例

3 週連続して $400 \mathrm{ml}$ の貯血を行った症例 8 では術直 前の $\mathrm{Hb}$ は貯血前より $2.4 \mathrm{~g} / \mathrm{dl}$ 低下した。症例 9 （図 4 ）は入院時より貯血を開始し, 術前治療期間を含め て 2 週間毎に $400 \mathrm{ml}$, 計 $1200 \mathrm{ml}$ の貯血を行い, 貯血後 の $\mathrm{rHuEPO}$ 投与は $18000 \mathrm{IU}$ を 1 回の皮下注で行った. 各 $400 \mathrm{ml}$ 貯血の 2 週間後には $\mathrm{Hb}$ 值は貯血前の值に回 復し, 手術前日には入院時の $\mathrm{Hb}$ 值 $11.4 \mathrm{~g} / \mathrm{dl}$ に回復 した. 手術では $1015 \mathrm{ml}$ の出血に対して $1200 \mathrm{ml}$ の自己 血輸血を行った. 術後 1 週および 4 週の $\mathrm{Hb}$ 值は 12.0 と $13.4 \mathrm{~g} / \mathrm{dl}$ で良好な回復がみられた。

症例10（図 5) は上顎骨骨肉腫の症例で, 術前の CDDP と ADR の併用療法による骨髄機能抑制が考 えられたので, まず入院時に $400 \mathrm{ml}$ の貯血を行ったが, 

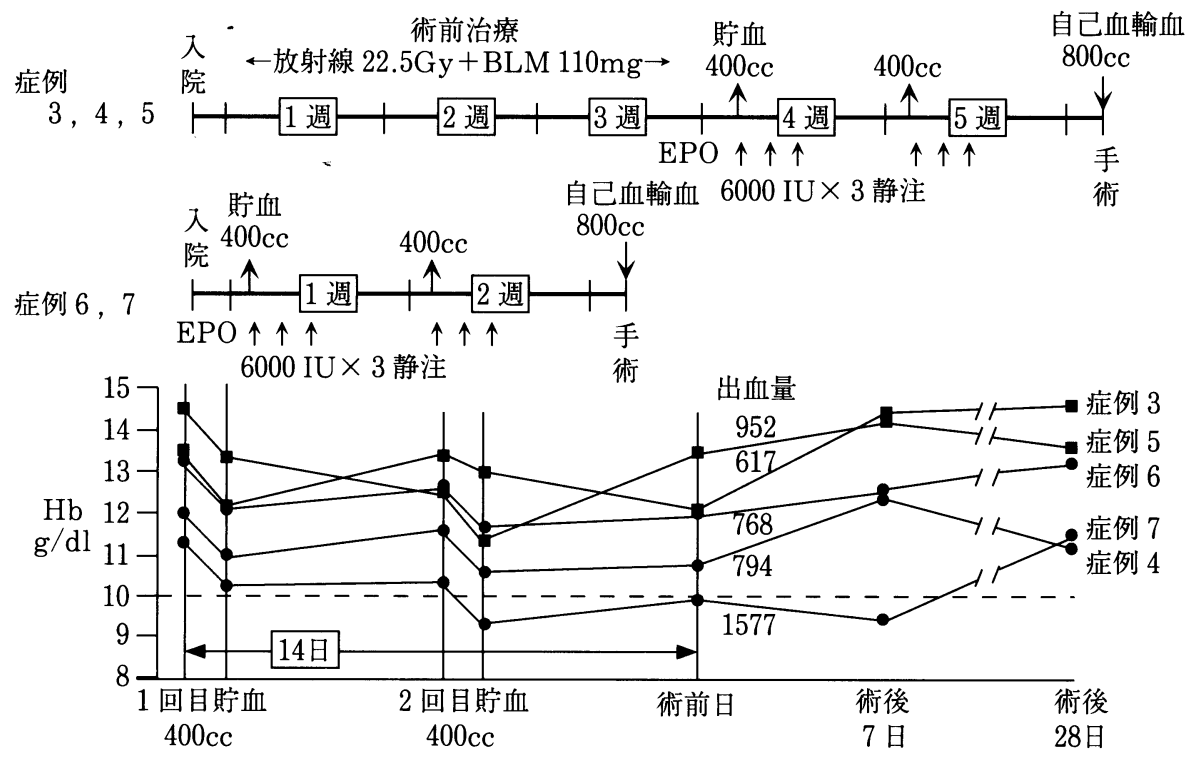

図 $3800 \mathrm{cc}$ 貯血症例

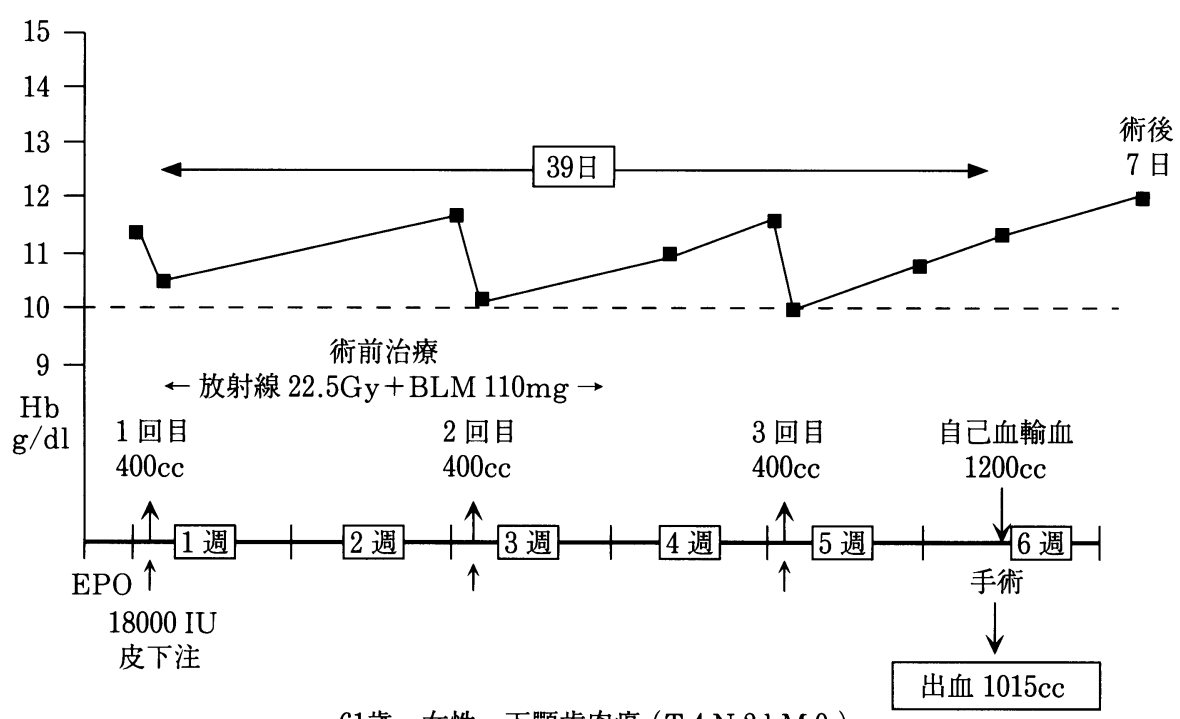

図 4 症例 $9 \quad 1200 \mathrm{cc}$ 術前貯血による $\mathrm{Hb}$ 值の変動

手術日までにMAP 保存液の保存期間 6 週間を越え るため, 凍結保存とした. 術前治療終了時 $\mathrm{Hb}$ は $10.6 \mathrm{~g}$ $/ \mathrm{dl}$ となり,さらに $400 \mathrm{ml}$ の貯血により 10 以下となっ たが, $\mathrm{rHuPO}$ 投与により手術前日には $11.1 \mathrm{~g} / \mathrm{dl}$ と良 好な回復がみられた．上顎全切除術による $1631 \mathrm{ml} の$ 出血に対して術直前 $400 \mathrm{ml}$ 採血による希釈式を併用し, $1600 \mathrm{ml}$ の自己血輸血を行った。

\section{4 ) $1600 \mathrm{ml}$ 貯血症例}

連続 4 週間の貯血は困難であったので, 入院時と術 前治療開始前後の 2 週間に $400 \mathrm{ml}$ を 2 回と術前治療終 了から手術までの 2 週間に $400 \mathrm{ml}$ を 2 回, 計 $1600 \mathrm{cc}$ の 貯血を行った。1例（症例11）は手術までに 6 週間の 液状保存期間を越えるため, スイッチバック法 ${ }^{3)}$ を採 用した。

症例13（図 6 ）は下顎歯肉癌（T 4 N $2 \mathrm{cM} 0$ ) の症例 


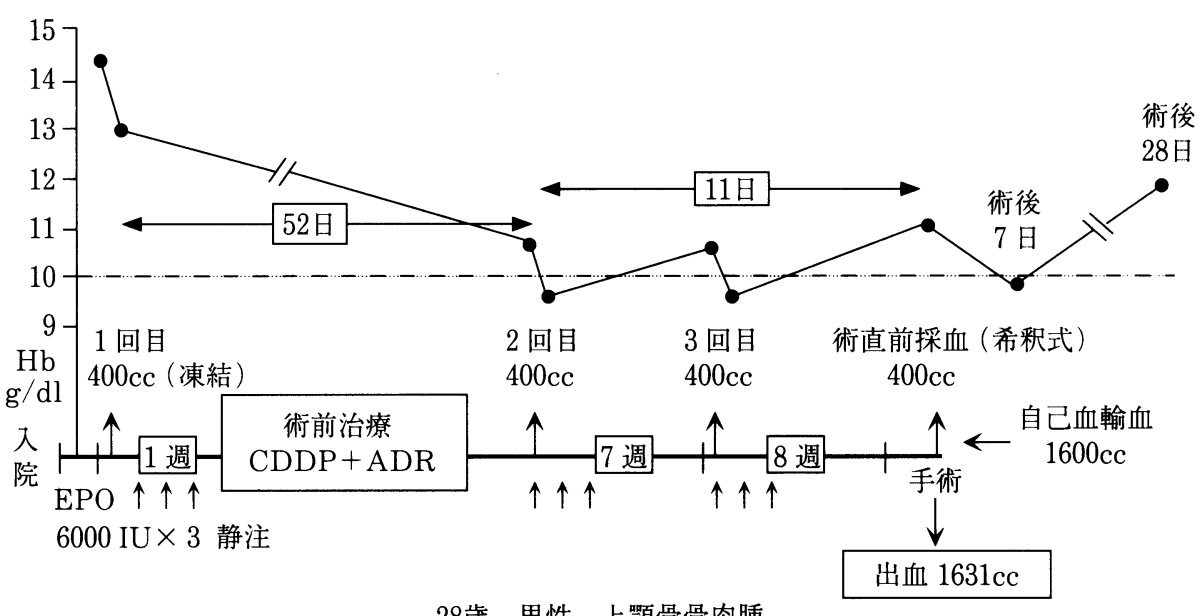

図 5 症例10 $1200 \mathrm{cc}$ 術前貯血による $\mathrm{Hb}$ 值の変動

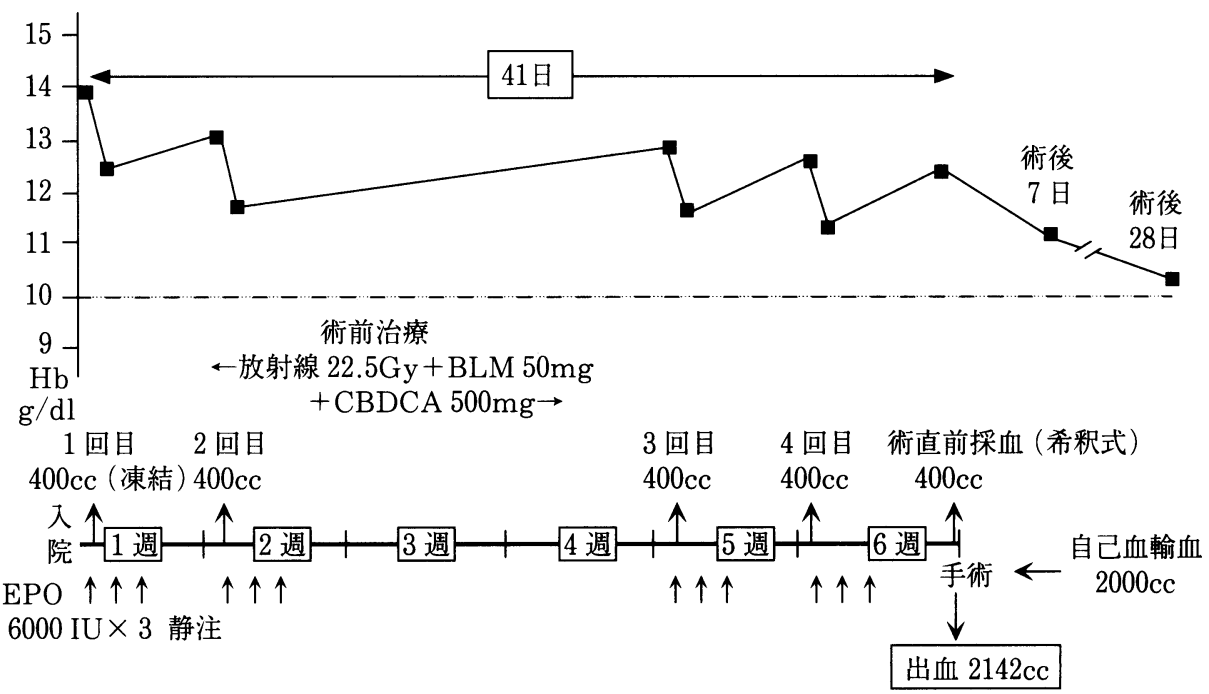

51 歳 男性 下顎歯肉癌 ( T $4 \mathrm{~N} 2 \mathrm{cM} 0$ )

図 6 症例 $13 \quad 1600 \mathrm{cc}$ 術前貯血による $\mathrm{Hb}$ 值の変動

で，1回目の貯血分が手術までに保存期間を越える可 能性があったので, 凍結保存としたが, 結果的には 3 週間の術前治療をはさみ 6 週間以内 $(41$ 日) で手術を 行った. 術前治療前後に $400 \mathrm{ml} 2$ 回づつの貯血を行っ たが, $\mathrm{Hb}$ 值の回復は良好で, $1.3 \mathrm{~g} / \mathrm{dl}$ の低下にとど まり, 術直前の $\mathrm{Hb}$ 值は $12.7 \mathrm{~g} / \mathrm{dl}$ であった. 手術は下 顎骨半側切除, 両側頸部郭清術, 腹直筋皮弁とチタン プレートによる再建を行い, $2142 \mathrm{ml}$ の出血に対して, 貯血 $1600 \mathrm{ml}$ に術直前採血 $400 \mathrm{ml}$ を加え, $2000 \mathrm{ml}$ の自 己血輸血を行った. 他の 2 例の $1600 \mathrm{ml}$ 貯血による $\mathrm{Hb}$
の低下は $2.3 \mathrm{~g} / \mathrm{dl}$ と $4.3 \mathrm{~g} / \mathrm{dl}$ で, 術直前の $\mathrm{Hb}$ は 10.6 $\mathrm{g} / \mathrm{dl}$ と $10.0 \mathrm{~g} / \mathrm{dl}$ であったが, 全身状態に問題なく, 予定通りの貯血と手術の施行が可能であった.

\section{4.rHuEPO (エポジン®) の作用}

1) エポジンのの効果

貯血後に使用した rHuEPO の有効性を評価するため, 手術前日までの $\mathrm{Hb}$ 增加量としてデルタ $\mathrm{Hb}(\Delta \mathrm{Hb})$ を表 3 の式により算出し, 貯血量別有効性判定基準 4) にしたがって評価した.この結果, 著効 5 例, 有効 3 例, やや有効 2 例, 無効 2 例で, $67 \%$ の有効率であった. 
表 3 遺伝子組換えヒトエリスロポエチン（エポジ ン ${ }^{\circledR}$ の効果

\begin{tabular}{rrrrrrr}
\hline 症例 & 年齢 & 貯血量 & 貯血期間 & $\Delta \mathrm{Hb}^{*}$ & \multicolumn{2}{c}{ 判 定** } \\
\hline 1 & 49 & 400 & 1 週間 & 0.0 & 無 & 効 \\
2 & 33 & 400 & 1 & 4.6 & 著 & 効 \\
\hline 3 & 56 & 800 & 2 & 1.1 & 著 & 効 \\
4 & 73 & 800 & 2 & -0.2 & 無 & 効 \\
5 & 59 & 800 & 2 & 0.9 & 有 & 効 \\
6 & 70 & 800 & 2 & 0.9 & 有 & 効 \\
7 & 72 & 800 & 2 & 0.6 & やや有効 \\
\hline 8 & 61 & 1200 & 6 & 3.9 & 著 & 効 \\
9 & 52 & 1200 & 3 & 1.9 & 著 & 効 \\
10 & 28 & 1200 & 9 & 2.3 & 著 & 効 \\
\hline 11 & 64 & 1600 & 7 & 1.6 & 有 & 効 \\
12 & 70 & 1600 & 6 & 1.2 & やや有効 \\
13 & 51 & 1600 & 6 & 3.0 & 著 & 効 \\
\hline
\end{tabular}

$\mathrm{Hb}$ 増加量 $*$ =(術直前 $\mathrm{Hb}$ 一投与開始日 $\mathrm{Hb})+\Sigma$ 貯血直前 $\mathrm{Hb} \times$ 貯血量 $\Delta \mathrm{Hbg} / \mathrm{dl})$

循環血液量

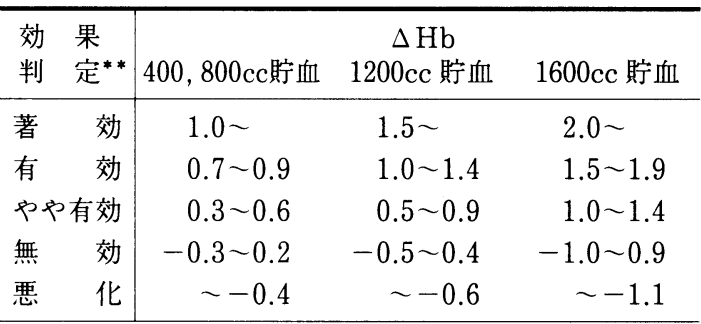

2 ) 副作用

エポジン®投与後に頭重感の訴えが 2 例, 倦怠感の 訴えが 1 例あったが, 投与前後に脈拍や血圧その他の バイタルサインの変動はなく, 投与中止や貯血に影響 するような重篤な副作用は見られなかった。また採血 時や貯血, 戻し輸血に伴うトラブルは全く生じなかった。

\section{考察}

手術における大量出血に対して輸血は不可欠であり， 近代外科の発展に輸血が大きく貢献してきたことはい うまでもない.しかし一方では，通常行われている同 種血輸血によって輸血後肝炎, AIDS 等のウイルス感 染症や移植片対宿主病 (GVHD) の発症など輸血副作 用が医学的のみならず社会的にも大きな問題となって いる ${ }^{5)}$. 特に GVHD はまれではあるが致命的である ため, 平成 8 年 4 月に同種血輸血によるGVHD に対 する厚生省緊急安全性情報 6 ) が出され, 予定された手
術では自己血輸血の実施を考慮するようにとの勧告が 行われた. 口腔外科領域においても舌癌手術患者の輸 血後 GVHD による死亡例が報告されている ${ }^{7}$ ). 輸血 感染症については現時点では一応の安全性が確立して いるが, WHO は1996年世界保健報告8)において, 過 去20年間でエイズ, エボラ出血熱，狂牛病など 30 種の 人と動物の新たな感染症が見つかり，その多くは治療 法や予防ワクチンがまだ確立されていないと発表して おり，いつまた輸血による新種の感染症が起こり，工 イズ騒動のようなパニックが起こるとも限らないのが 現状である. 自己血輸血はこれらの輸血副作用の発症 を防止できる唯一の輸血療法であり，その普及は時代 の要求となっている.

自己血輸血法は術前貯血式, 術直前採血による希釈 式, 術中・術後出血回収式があるが，このうち液状保 存での貯血式は，簡便で経済的かつ安全で確実性があ るため, 最も汎用性がある自己血輸血法である ${ }^{1}$ ). 貯 血式自己血輸血の適応として, 緊急を要さない待機 （予定）手術であること, 手術術式が一定で術中出血量 が子測できること，全身状態が良好（術前に貧血のな い症例）であること，などがあげられ，口腔外科領域 では外科的矯正手術が最も良い対象とされてきた $\left.{ }^{9}, 10\right)$ 。 しかし最近の顎矯正手術における技術の発達と確立や 手術器具の開発普及により, 多くの症例, 特に最も手 術頻度の高い下顎枝矢状分割術においては出血量が抑 えられてきており ${ }^{11)}$, 輸血の必要性がなくなっている のが現状である

一方, 口腔覀性腫場の手術では拡大手術や種々の再 建に伴う出血のため, 口腔外科領域の手術においては 輸血する症例が最も多い. 当科において過去 2 年 2 か 月間に手術を行った口腔悪性腫崵手術例88例のうち, $600 \mathrm{ml}$ 以上の出血が40例にみられ，このうち 24 例 (60\%) に同種血輸血が行われていた. 残り16例は同種 血輸血が回避されたものの 7 例において術後に $\mathrm{Hb}$ 值 が $10 \mathrm{~g} / \mathrm{dl}$ 以下の䡠血がみられた. 結局, 悪性腫瘍手 術88例のうち同種血輸血が行われた24例にこの 7 例を 加えた 31 例 $(35 \%)$ が自己血輸血の対象となるものと 思われた．また同種血輸血は悪性腫瘍患者の免疫能を

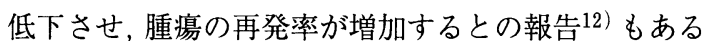
ことから, 悪性腫瘍患者の輸血にこそ術前貯血式自己 血輸血の適応があり，その実施が望まれる。しかし， 一般に悪性腫瘍患者においては, 待機手術でないこと や術前の放射線療法や化学療法による骨髄機能抑制, それに伴う貧血や全身状態の低下などの問題点があり， 術前の自己血貯血が困難であるとされてきた。ところ が赤血球造血因子製剤である遺伝子組換えヒトエリス ロポエチンが貯血後の貧血の改善に用いることができ るようになったこと ${ }^{2)}$ やMAP 保存液により 6 週間 の液状冷蔵保存が可能となったこと ${ }^{13)}$ から, 全身状態 や造血能の低下した患者においても術前の自己血貯血 
が可能となってきた。

そこでまず口腔悪性腫瘍の手術において, 術前貯血 が可能であるかどうかについて検討を行った. 当科で の術前治療は, 多くの症例において 3 週間の放射線 · BLM 同時併用を行っているため, 悪性腫瘍の診断が ついて入院し, 各種の検査後, 術前治療を開始するま でに最短で 1 週間, 術前治療期間の 3 週間, さらに術 前治療後手術までの 2 週間の休止期間を加えると, 診 断から手術まで 6 週間となり，ちょうど MAP 保存液 の保存期間と同じである.術前治療を行わない症例に おいては, 診断がついた後, あるいは再発や転移が判 明してから, 局所と全身の各種検査を行いつつ入院の 段取りをつけて手術にいたるまで最低 2 週間は必要で ある (図 3 ). rHuEPO の投与により，1 週間毎に 400 $\mathrm{ml}$ の貯血が可能であることから ${ }^{14)}$, 術前治療後手術 までの 2 週間あるいは術前治療を行わない症例でも各 種検査に必要な 2 週間を利用して最低でも $800 \mathrm{ml}$ の貯 血が可能である.この時期に患者の全身状態からみて 貯血可能かどうかについては, 術前治療を行った 32 症 例のうちほとんどの症例が入院時 $\mathrm{Hb}$ 值が $12 \mathrm{~g} / \mathrm{dl}$ 以 上と良好で，また当科での術前治療の主体である BLM110mg と $22.5 \mathrm{~Gy}$ の放射線併用療法は骨髄抑制が ほとんどないため $\mathrm{Hb}$ 值の低下は平均 $0.43 \mathrm{~g} / \mathrm{dl}$ と軽 度であり, 術前治療後30例において貯血可能である 11 $\mathrm{g} / \mathrm{dl}$ 以上の $\mathrm{Hb}$ 值を保っていた.

貯血式自己血輸血を適応する場合, 手術術式が一定 で術中出血量が予測できることが重要な条件の1つで あるが, 口腔悪性腫瘍の手術術式とそれに伴う出血量 は原発巣の進展範囲や転移の有無, 再建の方法さらに は術者の技術や経験のレベルによって大いに異なって くる. そこで, 手術術式を原発巣の切除の程度と頸部 郭清および再建の有無によって 7 群に分類して出血量 を検討したところ, 出血量の予測はある程度可能であ ることがわかった. 表 1 に示す各群の平均出血量は上 顎全切除 ( $\mathrm{C}$ 群) では約 $1000 \mathrm{ml}$, 全頸部郭清術単独 (D 群) では約 $500 \mathrm{ml}$, 原発巣切除と頸部郭清を含めた enbloc 手術（E 群）では約 $800 \mathrm{ml}$ ，有茎筋皮弁や遊離 （筋）皮弁による再建が加わった症例（F 群）では約 $1000 \mathrm{ml}$, 原発巣の切除が広範囲の軟組織や上下顎骨を 含んだ拡大切除 (G 群) では約 $1600 \mathrm{ml}$ であったこと から, 自己血輸血を行う場合, C 群 $800 \mathrm{ml}, \mathrm{D}$ 群 $400 \mathrm{ml}$, $\mathrm{E}$ 群 $800 \mathrm{ml}, \mathrm{F}$ 群800 1200ml, G 群1200 1600ml を一 応の貯血量の目安として準備を行うこととした。

自己血輸血を行った13症例のうち出血量が貯血量を 大きく上回り同種血輸血の併用を余儀なくされた症例 が 2 例にみられた. 逆に出血量が予想より少なかった 症例 $(1600 \mathrm{ml}$ 貯血に対して $936 \mathrm{ml}$ の出血) では $400 \mathrm{ml}$ が廃棄された。 その他の症例についてはおおむね予測 出血量に対して予定どうりの貯血が可能であった. 特 に 2 週間に $800 \mathrm{ml}$ の貯血に対しては, rHuEPOの投与
下で全く問題なく行い得た. しかし, $1200 \mathrm{ml}$ 貯血の場 合 $400 \mathrm{ml}$ を 3 週間連続で貯血した症例 8 (図 4) では 3 回目には Hb の回復がほとんどみられなかった，開心 術症例や股関節手術症例では $\mathrm{rHuEPO}$ の投与下に 3 週間で $1200 \mathrm{ml}$ の自己血の貯血が十分可能であると報 告14,15) されているが対象が比較的若い健康な症例で あり，悪性腫瘍患者で放射線照射や抗癌剤の投与を行っ た患者には $400 \mathrm{ml}$ の 3 週間連続貯血は負担が大きいも のと思われた. 吉田ら ${ }^{16)}$ は $400 \mathrm{ml}$ 献血を行った健康な 成人女性の血液学的動態を検索した結果, 14日目には 網状赤血球の割合および MCHC 值が正常化し, 平均 血清 $\mathrm{EPO}$ 濃度は最高値を示したことから，自己血 400 $\mathrm{ml}$ 採血後 2 週目が最も手術に適した時期であると述 べている. 今回 $1200 \mathrm{ml}$ の貯血を行った 3 例のうち症 例 9 では骨髄抑制があまりみられない放射線・BLM 術前併用治療の前 (入院時), 中, 後に 2 週間隔で $400 \mathrm{cc}$ 3 回の貯血を行ったが, $\mathrm{Hb}$ の回復は良好でいずれも 貯血前の $\mathrm{Hb}$ 值に回復しており（図 4)，貯血の間隔は 2 週間が理想であると思われた。今後，骨髄抑制があ まりない術前治療の場合の $1200 \mathrm{ml}$ の貯血には術前治 療期間も含め $400 \mathrm{ml}$ を 2 週間隔で 3 回行うこととした.

一方， 6 週間以上をかけて CDDP と ADR の多剂 併用療法を行った症例10では, 全身状態良好な入院時 にまず 1 回目の貯血を行ったが，手術までに 6 週間を 越えるため凍結保存とした。この症例はかなり強い骨 髄抑制が認められ, 術前治療終了後 2 回目の採血時 $\mathrm{Hb}$ 值は14.4から $10.6 \mathrm{~g} / \mathrm{dl}$ に低下したが, $\mathrm{rHuEPO}$ 投与に よる $\mathrm{Hb}$ 值の回復は良好で, 術前治療後 $800 \mathrm{ml}$ を貯血 し, 計 $1200 \mathrm{ml}$ の貯血が可能であったうえに手術前日に は11.1g/dl まで回復した (図 5 ). 佃ら ${ }^{17)}$ は 5 -fluorouracil, THP-adriamycin, cisplatine, peplomycin などの頭頸部癌でよく用いられるいずれの化学療法や 放射線療法による筫血に対しても，rHuEPOは筫血の 防御や改善に有効かつ安全性の高い薬郕であることを 報告している. 吉田ら ${ }^{18)}$ は術前放射線・化学療法後の 口腔癌患者に対し $800 \mathrm{ml}$ を目標とした術前貯血におい て, rHuEPO 投与群と非投与群を比較し, 投与群では 限られた期間にほほ目標の $800 \mathrm{cc}$ 貯血し得たのに対し， 非投与群では赤血球数や $\mathrm{Hb}$ 值が採血前より有意に低 下したため, 貯血量が少なくなり，貯血に要した期間 も長くなったと述へ, $\mathrm{rHuEPO}$ 投与により確実かつ安 全な自己血貯血が可能であることを示した. 今回自己 血輸血を行った13例のエポジンのの効果は著効 5 例, 有効 3 例で $67 \%$ の有効率であった．無効の 2 例を含め エポジン®の使用によりほとんどの症例において決めら れた期間内に目標量の貯血を行うことが可能であった.

自己血輸血を行う際には一定の期間にどれだけの貯 血が可能であり, どの程度の出血まで対応できるかの 問題がある. 今回最も貯血量の多かった $1600 \mathrm{ml}$ の場 合には，まず術前治療開始前に $400 \mathrm{ml}$ 貯血を 2 回，術 

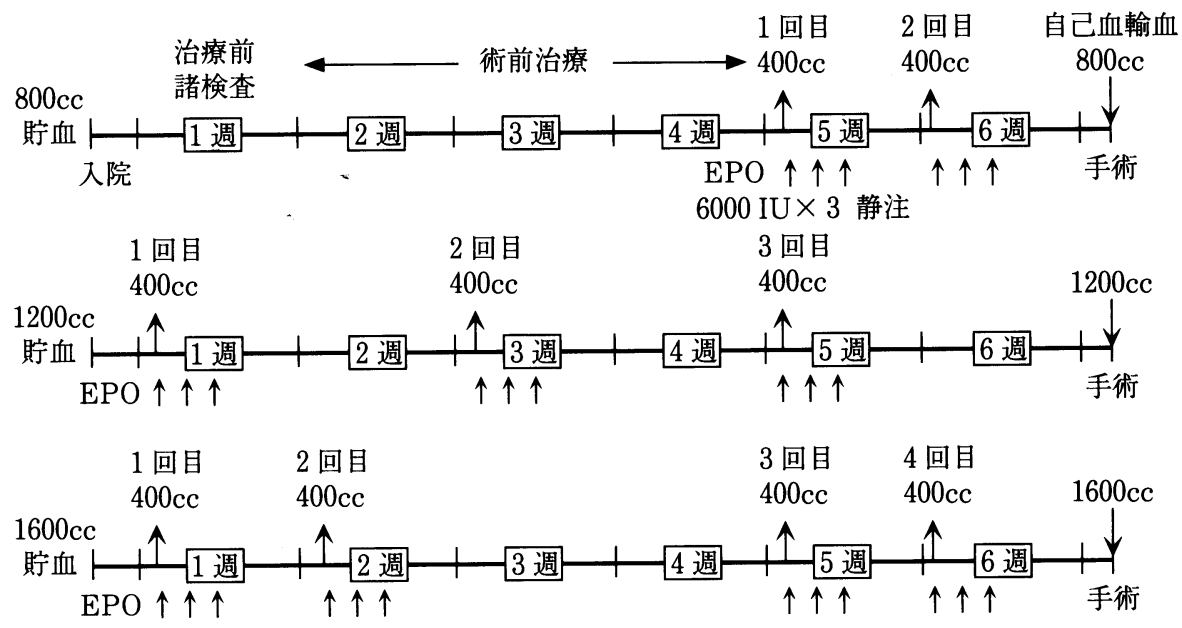

図 7 術前貯血スケジュール

前治療終了から手術までに 2 回の貯血を行ったが，手 術までに 6 週間を越える可能性があったので，初回貯 血分はスイッチバックや凍結保存を行った.しかし，2 例では 6 週間以内に $1600 \mathrm{ml}$ の貯血を行い得た。この 3 症例の $\mathrm{Hb}$ の低下は $1.3,2.3,4.3 \mathrm{~g} / \mathrm{dl}$, 術直前の $\mathrm{Hb}$ は $12.7,10.6,10.0 \mathrm{~g} / \mathrm{dl}$ で症例によってかなり差がみ られたが，いずれも全身状態に問題なく，予定通り の貯血と手術の施行が可能であった。このように6 週間で $1600 \mathrm{ml}$ の貯血は必ずしも容易ではないが， rHuEPOの使用により可能であった. 症例 $13 て ゙ は 1600$ $\mathrm{ml}$ の貯血と術直前に $400 \mathrm{ml}$ 採血による希釈式を併用 することで2142cc の出血の対応が可能であった．当科 における過去 3 年間の口腔悪性腫瘍の手術 128 例のう ち最大の出血量は $2496 \mathrm{ml}$ であり，2000 $\mathrm{ml}$ 以上出血し た症例はわずか 5 例 $(4 \%)$ であった. それゆえ，口腔 悪性腫瘍の手術では $1600 \mathrm{ml}$ の貯血が必要な症例は非 常に少なく, ほとんどの症例では800から $1200 \mathrm{ml}$ の貯 血があれば同種血輸血は回避可能であると考えられた. しかし，手術までの期間が限られている時には予測さ れる出血量に対し十分な貯血が確保できない場合があ り，基本的にはなるべく出血しないような手術手技， 麻酔管理を心がけるべきである. 当科では自己血輸血 を開始してからは貯血量を念頭において, 確実で丁寧 な止血操作で手術を行うようになり, 最近は出血量が 隇少する傾向にある.

自己血輸血にもうひとつの問題として, 術前貯血式 は患者が担癌状態の時に貯血するため, 末梢血に循環 している癌細胞の存在が上げられる. Sandberg ら ${ }^{19)}$

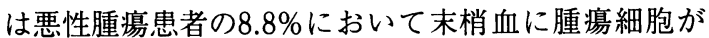
存在していたことを報告しており，そのような自己血 輸血による腫瘍細胞の播種によって, 転移や再発を引
き起こす可能性が指摘されている。これに対して，吉 田ら 20,21$)$ MAP 保存液中で悪性腫瘍が 1 週間以上 生存できないことや白血球除去フィルターにより癌細 胞が完全に除去できることを明らかとし，これらの処 置により自己血輸血を安全に行い得ると述べている． 当科では術前 1 週間以内の貯血や希釈式の術直前脱血 など, MAP 液に 1 週間以上保存されない血液や凍結 保存した血液を輸血する場合には白血球除去フィルター を用いて, 存在するかもしれない腫瘍細胞の除去を心 がけている。

以上の経験から $800 \mathrm{ml}, 1200 \mathrm{ml}, 1600 \mathrm{ml}$ の貯血スケ ジュールを図 7 のごとく設定した．原則として MAP 保存液による液状保存で, 6 週間以内の貯血スケジュー ルとし，貯血のために手術時期を遅らせることはしな い. しかし，抗癌剂の多剂併用療法による術前治療な どで手術までに 6 週間を越えるような場合には $1 ， 2$ 回目の貯血は凍結保存が必要となる.今後このスケジュー ルに従った貯血による自己血輸血を行い, 症例を重ね て貯血量に応じた至適貯血法を検討してゆきたい。ま た rHuEPOの投与方法（静注と皮下注のどちらが良 (か) や自己血輸血症例の免疫能, 術後感染, 予後に ついて同種血輸血症例と比較検討してゆく予定である。

\section{結語}

当科における口腔悪性腫瘍手術での出血量と輸血の

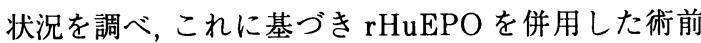
貯血式自己血輸血を施行し，口腔悪性腫瘍手術におけ る自己血輸血の適応, 方法, 問題点を報告した。

1. 1993年 4 月から1995年 5 月までに行われた口腔 悪性腫瘍手術 88 例のうち, $600 \mathrm{ml}$ 以上の出血は 40 例み 
られ，このうち同種血輸血が24例 $(60 \%)$ に行われて いた。

2. 手術術式を原発巣の切除の程度と頸部郭清術お よび再建の有無によって 7 群に分類し出血量を検討し たところ, 出血量のある程度の予測は可能であること が分かった.

3.1995 年 6 月以降の 1 年間に $600 \mathrm{ml}$ 以上の出血が 子測された 13 例に, rHuEPO 投与下に術前貯血による 自己血輸血を施行した．眝血量は $400 \mathrm{ml}$ から $1600 \mathrm{ml}$ で平均 $1015 \mathrm{ml}$ であった。

4. $\mathrm{rHuEPO}$ の効果は13例中, 著効 5 例, 有効 3 例 で67\%の有効率であった. 大量の出血が予測されるロ 腔悪性腫湯の手術に $\mathrm{rHuEPO}$ 投与下で術前貯血式自 己血輸血が適応であることが示された。

5. MAP 保存液による 6 週間以内の $800 \mathrm{ml}, 1200$ $\mathrm{ml}, 1600 \mathrm{ml}$ の貯血スケジュールを設定した。

\section{謝辞}

貯血式自己血輸血を行うにあたり，ご指導をいただき ました鹿児島大学歯学部口腔外科学第 1 講座吉田雅司先 生に深謝いたします.また, 貯血にご協力いただき種々ご 助言いただきました九州大学医学部輸血部稲葉頌一講師 に深謝いたします。

本研究の概要は第50回日本口腔科学会 (1996年 4 月： 鹿児島), 第41回日本口腔外科学会 (1996年11月：東京) および第51回日本口腔科学会 (1997年 4 月 : 新潟) で発 表した。

\section{引用 文 献}

1）前田平生 : 自己血輸血とは. 造血因子 $5: 132$ 1361994

2) Goodrough, L.T., Rudnick, S., et al.: Increased preoperative collection of autologous blood with recombinant human erythropoietin therapy. N. Engl. J. Med. 321: 1163-1168 1989.

3）富士武史, 桜井 隆共著 : 整形外科自己血輸血 マニュアル 第 1 版, 金原出版, 東京, 1993, 5253 頁.

4）前田平生, 東 博彦, 他：整形外科領域におけ る自己血輸血を用いた手術施行患者に対するエ ポエチンベータ (EPOPCH) の臨床評価. 医学 のあゆみ 161: 163-176 1992.

5）遠山 博 : 輸血の歴史と同種血輸血の副作用 · 合併症. 造血因子 5: 122-1301994.

6）厚生省薬務局：緊急安全性情報 No.96-1, 輸血用血液による輸血後移植片対宿主病 (GVHD) について. 日本薬剤師会雑誌 48 (巻
末綴込)：1-4 1996.

7）金 健三, 植野 茂, 他：舌癌手術後に発症し た移植片対宿主病 (GVHD) の1例. 日口外誌 37: 1159-1164 1991.

8) World Health Organisation: World Health Report 1996. Journal of Communicable Diseases 28: 215-219 1996.

9）久保誼修, 金 健三, 他 : 大阪歯科大学第 1 口 腔外科における顎矯正手術の臨床統計的観察。 日口診誌 $2: 128-1371989$.

10）中西 徹, 嶋田 淳, 他：䫟矯正手術における 自家血輸血の応用. 日歯麻誌 19: 343-349 1991.

11）宮手浩樹,横田光正,他：当科過去 7 年間にお ける顎矯正手術の臨床統計的観察日. 䫟変形誌 $7: 31-391997$.

12) Blumberg, N., Heal, J., et al.: Further evidence supporting a cause and effect relationship between blood transfusion and earlier cancer recurrence. Ann. Surg. 207: $410-4151988$.

13）福岡自己血輸血研究会編 : 自己血輸血ハンドブッ ク. 改訂版, 九州大学出版会, 福岡, 1995, 30-32 頁.

14）前田平生, 東 博彦, 他：整形外科領域におけ る貯血式自己血輸血施行手術患者に対する Recombinant Human Erythropoitin (EPOCH) の臨床評価一多施設共同用量比較試験一. 現代 医療 25: 1068-1086 1993.

15）許 倰鋭, 尾本良三 : 心臓外科領域における自 己血輸血のエリスロポエチンによる応用. 造血 因子 $5: 137-1411994$.

16）吉田雅司,杉原一正, 他 : $400 \mathrm{ml}$ 採血後の造血 過程に関する血液学的検討. 日口外誌 41: 7217251992 .

17）佃守, 持松いずみ, 他：遺伝子組換えヒト Erythropoietin の頭頸部癌治療への応用一化 学療法, 放射線治療との併用一. BIOTHERAPY $6: 603-6101992$.

18）吉田雅司, 杉原一正, 他 : 口腔癌患者の術前貯 血式自己血輸血療法における遺伝子組換えヒト エリスロポエチンの有効性. 自己血輸血 $8: 39$ 451995.

19) Sandberg, A.A., Moore, G.E., et al.: The frequency of tumor cells in the bone marrow and blood. Cancer 11: 1180-1186 1958.

20）吉田雅司, 河野一典, 他 : 赤血球保存液におけ る悪性腫場細胞活性。自己血輸血 $7:$ 14-16 1994.

21）吉田雅司, 河野一典, 他 : 白血球除去フィルター の癌細胞除去能に関する実験的検討. 口科誌 44: 408-411 1995. 